\title{
Expression and enzymatic activity of phenylalanine ammonia-lyase and p-coumarate 3-hydroxylase in mango (Mangifera indica 'Ataulfo') during ripening
} \author{
M.A. Islas-Osuna and G.A. González-Aguilar \\ Center of Research in Food \& Development CIAD, \\ Hermosillo, Sonora, Mexico \\ *These authors contributed equally to this study. \\ Corresponding author: G.A. González-Aguilar \\ E-mail: gustavo@ciad.mx
}

H. Palafox-Carlos*, C.A. Contreras-Vergara*, A. Muhlia-Almazán,

Genet. Mol. Res. 13 (2): 3850-3858 (2014)

Received July 30, 2013

Accepted December 13, 2013

Published May 16, 2014

DOI http://dx.doi.org/10.4238/2014.May.16.10

ABSTRACT. Phenylalanine ammonia lyase (PAL) and $p$-coumarate
3-hydroxylase $(\mathrm{C} 3 \mathrm{H})$ are key enzymes in the phenylpropanoid pathway.
The relative expression of $P A L$ and $C 3 H$ was evaluated in mango fruit
cultivar 'Ataulfo' in four ripening stages (RS1, RS2, RS3, and RS4) by
quantitative polymerase chain reaction. In addition, enzyme activity of
PAL and C3H was determined in mango fruits during ripening. The $P A L$
levels were downregulated at the RS2 and RS3 stages, while C3H levels
were upregulated in fruits only at RS3. The enzyme activity of PAL
followed a pattern that was different from that of the $P A L$ expression,
thus suggesting regulation at several levels. For C3H, a regulation at
the transcriptional level is suggested because a similar pattern was
revealed by its activity and transcript level. In this study, the complexity
of secondary metabolite biosynthesis regulation is emphasized because
PAL and C $3 \mathrm{H}$ enzymes are involved in the biosynthesis of several 
secondary metabolites that are active during all mango ripening stages.

Key words: Mangifera indica L.; $p$-Coumarate 3-hydroxylase;

Enzymatic activity; Gene expression; Phenylalanine ammonia lyase

\section{INTRODUCTION}

Fruit ripening is a process that is developmentally regulated and derived from the coordination of numerous biochemical and physiological changes within the fruit tissue. This process leads to changes in firmness, color, taste, aroma, and texture of fruit flesh (Bapat et al., 2010; Singh et al., 2010). Phenolic compounds that are produced by the phenylpropanoid pathway have several metabolic roles and contribute to fruit pigmentation and to a defense response to diseases, insect attack, and stress that are common in many fleshy fruits during ripening (Boudet, 2007). Phenylpropanoid metabolism is a key biosynthetic pathway in all plant cells, but the regulation of all genes involved is specific to the type of plant tissue and the species (Singh et al., 2010). The relationship between the fruit ripening process and the biosynthesis of phenolic compounds is a complex topic to approach (Rinaldo et al., 2010). However, some studies reported evidence that the ripening process directly affects the phenylpropanoid pathway (Singh et al., 2010; Palafox-Carlos et al., 2012a).

There are several key enzymes that are involved in the phenylpropanoid pathway, including phenylalanine ammonia lyase (PAL), cinnamic acid 4-hydroxylase $(\mathrm{C} 4 \mathrm{H}), p$-coumarate 3-hydroxylase $(\mathrm{C} 3 \mathrm{H}), 4$-coumarate $\mathrm{CoA}$ ligase $(4 \mathrm{CL})$, and O-methyltransferase (OMT) (Vogt, 2010). The role of PAL is to drive the carbon flow from the aromatic amino acid L-phenylalanine to the production of 4-coumaroyl-CoA (Rösler et al., 1997; Rinaldo et al., 2010). The role of $\mathrm{C} 3 \mathrm{H}$ is related to the 3 -carbon hydroxylation (attaching of $\mathrm{OH}$ groups) of the aromatic ring in diverse phenol intermediates, especially in the $p$-coumaric acid hydroxylation to form caffeic acid (Nair et al., 2002; Abdulrazzak et al., 2006). Thus, the PAL and C3H gene products are necessary for the synthesis of almost all the phenolic compounds in this biosynthetic pathway.

Mango (Mangifera indica L.) fruit is not only an economically important fruit worldwide but also a good dietary source of antioxidants, such as ascorbic acid, carotenoids, and especially phenolic compounds (Ma et al., 2011). Different health-promoting properties have been revealed by these phenolics mainly because of their remarkable antioxidant capacity (Gonzalez-Aguilar et al., 2010). The highest phenolic content and antioxidant capacity among several mango varieties were reported for the Ataulfo variety (Manthey and Perkins-Veazie, 2009). Furthermore, the Ataulfo mango characteristic high content of phenolic acids, as well as the antioxidant capacity of this fruit, was correlated with its total phenolic content and composition (Palafox-Carlos et al., 2012a,b). Consequently, this study aimed to evaluate MiPAL and $\mathrm{C} 3 \mathrm{H}$ expression levels, as well as their corresponding enzyme activities, in mango fruit in different ripening stages.

\section{MATERIAL AND METHODS}

\section{Plant material}

Fresh mango fruit (average weight of 200-300 g) (M. indica L. 'Ataulfo') were har- 
vested from a field in Tepic, Nayarit, Mexico, and immediately transported to the laboratory for evaluation. Fruit were selected in accordance to their size, color, and appearance and fruit with defects or physiological disorders were discarded. Fruits were then sanitized with chlorinated water (200 ppm sodium hypochlorite) for $3 \mathrm{~min}$ and left to dry at room temperature $\left(23^{\circ}-26^{\circ} \mathrm{C}\right)$ for $1 \mathrm{~h}$. Fruits were selected by surface color and divided into 4 groups of 16 fruits each. A total of 4 ripening stages (RS) were established: RS1, representing mango with a yellow surface area of $0-10 \%$; RS2, 20-30\%; RS3, 70-80\%; and RS4, 100\% yellow color. The pulp was removed, cut into small pieces as quickly as possible, frozen in liquid nitrogen, and stored at $-80^{\circ} \mathrm{C}$.

\section{RNA isolation and cDNA synthesis}

Total RNA was isolated from the mango mesocarp tissue according to López-Gómez and Gómez-Lim (1992). The RNA quantity was estimated by absorbance at $260 \mathrm{~nm}$ using a Nano-Drop ND-1000 ultraviolet-visible light spectrophotometer (Nano Drop Technologies Inc., USA). The RNA integrity was detected by agarose gel electrophoresis under denaturing conditions. The cDNA synthesis was performed by reverse transcription of $5 \mu \mathrm{g}$ total RNA using the SuperScript II kit (Invitrogen, USA).

\section{Gene expression by real-time quantitative polymerase chain reaction (qPCR)}

Quantitative PCR was carried out using $\mathrm{iQ}^{\mathrm{TM}} \mathrm{SYBR}^{\circledR}$ Green Supermix (BIORAD, USA). All samples were PCR-amplified in triplicate in a $25-\mu \mathrm{L}$ total volume, which included $25 \mathrm{ng}$ cDNA as template, $12.5 \mu \mathrm{L} \mathrm{SYBR}^{\circledR}$ Green Master Mix, $1 \mu \mathrm{L} 5 \mu \mathrm{M}$ sense primer, and $1 \mu \mathrm{L} 5 \mu \mathrm{M}$ antisense primer. The specific primers used in qPCR for MiPAL were PAL-S 5'-GGCTGCAGCAATTATGGAAC-3' and PAL-A 5'-ACTTCAATCAGTGGGCCAAG-3'; the primers used for $\mathrm{MiC} 3 \mathrm{H}$ were $\mathrm{C} 3 \mathrm{H}-\mathrm{S}$ 5'-GGGTTGAAACTTGGAGCTTC-3' and C3H-A 5'-GACGAAATGATGCTTGACACC-3'; and the primers used for MiGAPDH were GAP-S 5'-GTGGCTGTTAACGATCCCTT-3' and GAP-A 5'-GTGACTGGCTTCTCATCGAA-3'. The PCR products were amplified in a Step-One ${ }^{\mathrm{TM}}$ Real-time PCR System (Applied Biosystems, USA). The amplification conditions were 40 cycles, including $95^{\circ} \mathrm{C}$ for $5 \mathrm{~min}, 95^{\circ} \mathrm{C}$ for $15 \mathrm{~s}$, $60^{\circ} \mathrm{C}$ for $1 \mathrm{~min}$, and $72^{\circ} \mathrm{C}$ for $5 \mathrm{~min}$. The PCR product specificity was confirmed by constructing a melt curve after amplification, raising the temperature from 60 to $95^{\circ} \mathrm{C}$, with an increase of $0.3^{\circ} \mathrm{C}$ every $15 \mathrm{~s}$; no template controls were included during each gene amplification. The $2^{-\Delta \Delta \mathrm{CT}}$ method was used to measure the relative mRNA amount of target genes (Livak and Schmittgen, 2001). Data were analyzed based on the threshold cycle (CT) value of each sample during PCR amplification, where $-\Delta \Delta \mathrm{CT}=-\left[\left(\mathrm{CT}_{\text {target }}-\mathrm{CT}_{\mathrm{GAPDH}}\right)-\left(\mathrm{CT}_{\text {Avgtarget }}-\mathrm{CT}_{\text {AvgGAPDH }}\right)\right]$, and Avg corresponded to the averaged CTs from the runs of day 1 . The results were expressed as relative mRNA steady-state levels of the target gene relative to RS1 and normalized to GAPDH expression levels. A nonparametric statistical analysis was performed by a Kruskal-Wallis analysis of variance (ANOVA) in addition to a median test using the Statistica Software 8.0.

\section{Enzymatic activity assays}

The crude extract for both PAL and the $\mathrm{C} 3 \mathrm{H}$ activity analysis was prepared using $2 \mathrm{~g}$ mango mesocarp tissue mixed with 0.2 g polyvinylpolypyrrolidone and homogenized in 25 
$\mathrm{mL}$ cold $5 \mathrm{mM}$ borate buffer, $\mathrm{pH} 8.5$, at low speed for $1 \mathrm{~min}$. The suspension was centrifuged at $15,000 \mathrm{~g}$ (Beckman Coulter, Allegra 62R, USA) for $15 \mathrm{~min}$ at $4^{\circ} \mathrm{C}$. The supernatant was collected and incubated for $5 \mathrm{~min}$ at $40^{\circ} \mathrm{C}$. The enzymatic reaction was performed with 1.9 $\mathrm{mL}$ extract and $100 \mu \mathrm{L} 100 \mathrm{mM}$ phenylalanine as a substrate. The mix was incubated for $1 \mathrm{~h}$ at $40^{\circ} \mathrm{C}$. After incubation, the mix was collected, and the absorbance was read using an Omega spectrophotometer (BMG Labtech Inc., Germany) with a microplate reader at a wavelength of $280 \mathrm{~nm}$. The values were calculated as $\mu$ moles cinnamic acid $\cdot \mathrm{h}^{-1} \cdot \mathrm{g}^{-1}$ fresh weight (FW).

The assay for $\mathrm{C} 3 \mathrm{H}$ activity was performed according to Schoch et al. (2001), with some modifications. An incubation mixture was prepared in a final volume of $500 \mu \mathrm{L}$ that contained $0.5 \mathrm{mM} p$-coumaric acid, $50 \mathrm{mM}$ potassium phosphate, $\mathrm{pH} 7.0$, and $250 \mu \mathrm{L}$ crude extract and was incubated in the dark for $1 \mathrm{~h}$ at $28^{\circ} \mathrm{C}$. The reaction was stopped with the addition of $60 \mu \mathrm{L}$ acetic acid and centrifuged at $18,000 \mathrm{~g}$ for $15 \mathrm{~min}$ at $4^{\circ} \mathrm{C}$. The supernatant was collected, and the absorbance was read at $325 \mathrm{~nm}$ using an Omega spectrophotometer (BMG Labtech Inc., Germany). The activity was reported as $\mu$ moles caffeic acid $\cdot \mathrm{h}^{-1} \cdot \mathrm{g}^{-1} \mathrm{FW}$. The statistical analysis was performed by one-way ANOVA with a 0.05 significance level using the NCSS (2007) software.

\section{RESULTS}

\section{$M i P A L$ is downregulated at RS2 and RS3 of mango}

The relative expression of MiPAL was evaluated during the ripening of mango Ataulfo fruit (Figure 1A). MiPAL was down regulated 10-fold at RS2 and 2.5-fold at RS3 $(\mathrm{P}<0.05)$. The MiPAL expression returned to the initial levels at RS4 when mango fruits were fully ripened $(\mathrm{P}>0.05)$.

\section{$\mathrm{MiC} 3 \mathrm{H}$ is expressed differentially from RS1 to RS4}

The relative expression of $\mathrm{MiC} 3 \mathrm{H}$ is shown in Figure 1B. $\mathrm{MiC} 3 \mathrm{H}$ was down regulated 10-fold at RS2 and then upregulated 0.6-fold at RS3. Regarding fully ripened mango fruits (RS4), the $\mathrm{MiC} 3 \mathrm{H}$ levels were down regulated 0.5 -fold relative to the initial levels $(\mathrm{P}<0.05)$.

\section{MiPAL and MiC3H enzymatic activities}

The MiPAL and MiCH3 enzymatic activity was evaluated during mango fruit ripening (Figure 2A and B, respectively). There were no significant differences in MiPAL activity in fruits from RS1 and RS2 (about $9 \mu$ moles cinnamic acid $\cdot \mathrm{h}^{-1} \cdot \mathrm{g}^{-1} \mathrm{FW}$ ); nevertheless, the MiPAL activity increased to $12 \mu$ moles cinnamic acid $\cdot \mathrm{h}^{-1} \cdot \mathrm{g}^{-1} \mathrm{FW}$ in mango at RS3 and remained similar in fruits at RS4. The MiC3H activity followed a pattern that was similar to that of $\mathrm{MiC} 3 \mathrm{H}$ expression: the activity decreased in fruits at RS2 (from 20 to $15 \mu$ moles cinnamic acid $\cdot \mathrm{h}^{-1} \cdot \mathrm{g}^{-1}$ $\mathrm{FW})$, increased in mango at RS3 (27 $\mu$ moles cinnamic acid $\left.\cdot \mathrm{h}^{-1} \cdot \mathrm{g}^{-1} \mathrm{FW}\right)$, and decreased in fruits at RS4 (17 $\mu$ moles cinnamic acid $\left.\cdot \mathrm{h}^{-1} \cdot \mathrm{g}^{-1} \mathrm{FW}\right)$. It is important to point out that mango, which is a climacteric fruit, showed the climacteric peak (highest respiration rate) at RS3 (data not shown). Moreover, these ripening stages were similar to those previously reported by our research group (Palafox-Carlos et al., 2012a). 


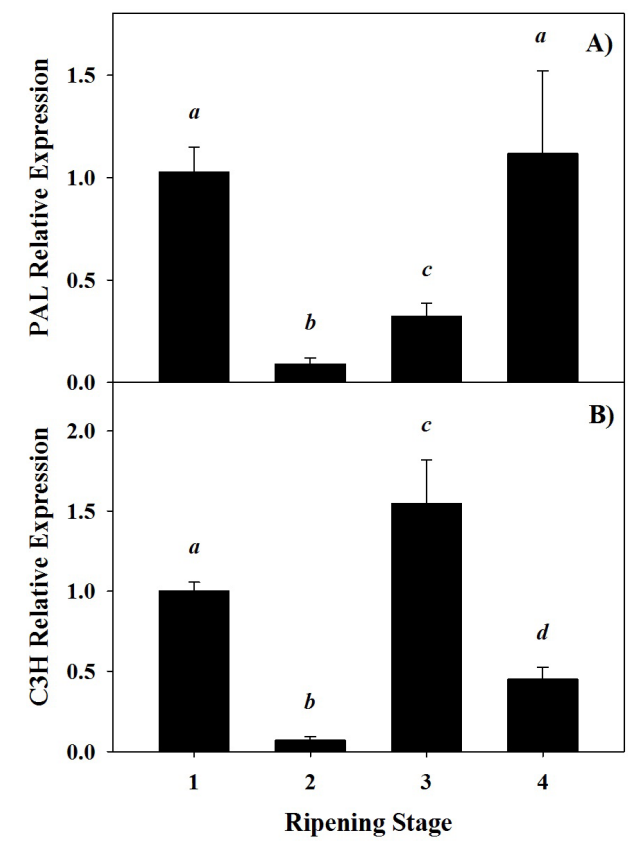

Figure 1. Relative expression of $M i P A L(\mathbf{A})$ and $M i C 3 H(\mathbf{B})$ at ripeness stages RS1, RS2, RS3, and RS4. Different letters show statistical difference $(\mathrm{P}<0.05)$ between stages of ripening. RS1 = fruit with a yellow surface area of $0-10 \%, \mathrm{RS} 2=20-30 \%, \mathrm{RS} 3=70-80 \%$, and RS4 $=100 \%$ yellow color. Data were normalized with the $G A P D H$ gene.

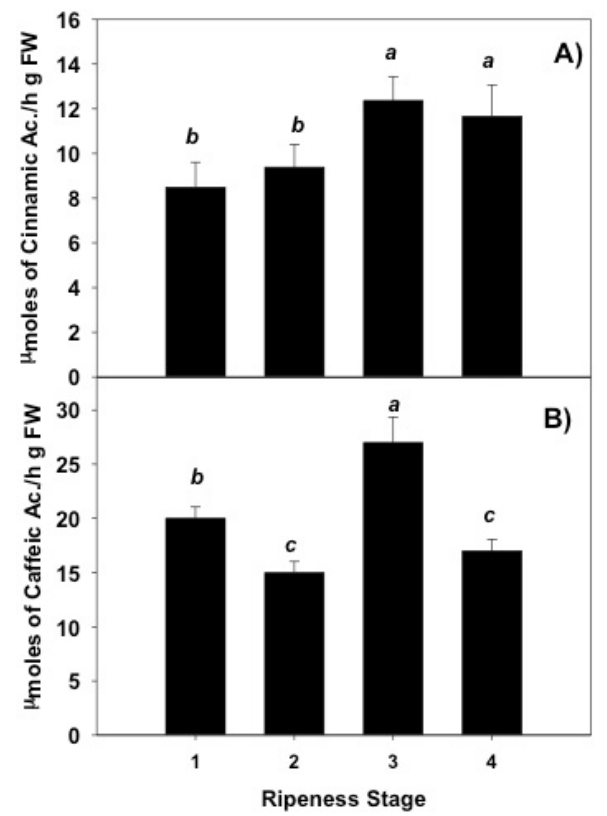

Figure 2. Enzymatic activity of $M i \mathrm{PAL}(\mathbf{A})$ and $M i \mathrm{C} 3 \mathrm{H}(\mathbf{B})$ in mesocarp of "Ataulfo" mango fruit during ripening. Different letters show statistical difference $(\mathrm{P}<0.05)$ between stages of ripening. RS1 $=$ fruit with a yellow surface area of $0-10 \%, \mathrm{RS} 2=20-30 \%, \mathrm{RS} 3=70-80 \%$, and RS $4=100 \%$ yellow color. 


\section{DISCUSSION}

Phenolic compounds that are produced by the phenylpropanoid pathway contribute to fruit pigmentation and the disease resistance response found in the ripening process of many fleshy fruits (Boudet, 2007). The relationship between such a process and the biosynthesis of phenolic compounds is a complex topic to study, and several questions remain to be resolved (Rinaldo et al., 2010). However, it was recently reported that the phenylpropanoid pathway and the biosynthesis of phenolic compounds are directly related to the ripening process (Singh et al., 2010; Palafox-Carlos et al., 2012a).

Despite the magnificent diversity in gene expression regulation, certain genes such as $P A L, C 4 H, C 3 H$, and $4 C L$, are considered to be key genes that are involved in the phenylpropanoid pathway (Vogt, 2010). This study focused on the $P A L$ and $C 3 H$ gene expression and their respective enzymatic activity in Ataulfo mango during ripening. The MiPAL expression levels were similar at the beginning and end of ripening, reflecting this gene activation at two different stages of the mango fruit ripening. Most of the necessary secondary metabolites with a role in ripening need to be synthesized in fruits at RS1, especially phenolic compounds and lignin (Giovannoni, 2004). This observation is in accordance with that of Shan et al. (2008), who suggested that the high expression levels of PAL during early stages of fruit development are related to either an increase in vascular tissue formation or structural modifications in the mesocarp. The MiPAL expression decrease in fruits at RS2 and RS3 takes place because respiration has not reached the climacteric peak (PalafoxCarlos et al., 2012a); thus, the biosynthesis of phenolic compounds is not as important in the climacteric stage as it is for RS4 (Gonzalez-Aguilar et al., 2010). This could explain the downregulation observed of MiPAL expression and the observed upregulation at the end of mango ripening in RS4.

MiPAL enzymatic activity did not correlate with the MiPAL expression: the enzyme was active during all of the evaluated ripening stages with a higher activity in mango fruits from RS3 and RS4. This lack of correlation suggested that the MiPAL regulation occurs at different levels (transcriptional and post-transcriptional). Our results agree with those of Promyou et al. (2007), who reported a lack of correlation between $P A L$ gene expression and PAL activity in Sucrier banana. An increase in PAL activity, in the case of Cherimoya fruit (Annona cherimola), was also exhibited without a significant increase in the biosynthesis of other phenylpropanoid compounds, even though the enzyme is a key part of the phenylpropanoid pathway (Assis et al., 2001). Consequently, because of the biological complexity of metabolism, it is important to point out that the "one gene leads to one protein, and one protein leads to one metabolite" principle is a simplistic and often incorrect notion that has been experimentally demonstrated (Mutch et al., 2005).

Until now, it has been difficult to fully understand the role of PAL and its enzyme isoforms, as well as their regulation. The $P A L$ gene from many plant tissues has been both cloned and characterized (Boudet, 2007). PAL seems to exist ubiquitously in higher plants as a family of genes; therefore, the presence of PAL isoforms is a common observation. The significance of this diversity is unclear; nonetheless, a degree of metabolic channeling within the phenylpropanoid metabolism that is partitioned into phenylpropanoid metabolism-specific branches may involve labile multienzyme complexes, including PAL-specific isoforms (Sreelakshmi and Sharma, 2008). For example, fruit color and flavor development in raspberry (Rubus idaeus) ripening 
relied on PAL encoded by a family of two genes (Ripall and Ripal2). The Ripall gene was associated with early fruit ripening events, whereas expression of Ripal2 was more easily correlated with later stages of flower and fruit development (Kumar and Ellis, 2001).

The MiPAL relative expression was evaluated throughout ripening. Concerning climacteric fruits, such as Ataulfo mango, the ethylene production during ripening is quite remarkable (Palafox-Carlos et al., 2012a), and it may be a PAL activity regulator. The presence of ethylene, according to Cai et al. (2006), is not only required for PAL enzyme synthesis but also to maintain its continuous high activity. In this study, differences in enzyme regulation were revealed in all of the ripening stages; furthermore, a detailed metabolite profiling will be required to determine the exact role that is played by each enzyme isoform to support the accumulation of specific phenylpropanoid products in fruits.

Regarding $\mathrm{MiC} 3 \mathrm{H}$ expression levels and enzymatic activity, higher levels of both were reached at RS3, the climacteric peak. The positive correlation between the expression of phenylpropanoid genes and their corresponding enzyme activity has been reported in fruits such as berries (Jaakola et al., 2002), strawberries (Almeida et al., 2007), banana (Chen et al., 2008), and others (Sanchez-Ballesta et al., 2000; Yingsanga et al., 2008; Pandit et al., 2010). These results suggested that $\mathrm{C} 3 \mathrm{H}$ expression is regulated at the transcriptional level. According to recent reports by Palafox-Carlos et al. (2012a,b), the highest total phenol quantity in Ataulfo mango pulp was in fruits at RS3; the major phenolic compounds that were found were phenolic acids. Chlorogenic and gallic acids were the most abundant; the highest content was found in the climacteric peak (Palafox-Carlos et al., 2012b). $\mathrm{C} 3 \mathrm{H}$ has been reported to be a gene that is responsible for the specific biosynthesis of phenolic acids (Abdulrazzak et al., 2006; Mahesh et al., 2007). Hence, the results obtained in this study are consistent with those recently reported in Ataulfo mango. This would explain why the highest $\mathrm{CH} 3$ expression corresponded with the highest phenolic acid content in mango fruit at the climacteric peak.

$\mathrm{C} 3 \mathrm{H}$ was originally named after its proposed function: C3-hydroxylation of $p$-coumaric acid and production of caffeic acid (Schoch et al., 2001; Franke et al., 2002); however, it is now known that this enzyme participates in other steps in the biosynthesis of phenolic acids and derivatives (Assis et al., 2001; Mahesh et al., 2007). Most of the studies that are reported in the literature were performed using other plants, such as Arabidopsis (Schoch et al., 2001), Coffea canephora (Mahesh et al., 2007), and Ginkgo biloba (Liu et al., 2008), or yeast overexpressing $\mathrm{C} 3 \mathrm{H}$ (Nair et al., 2002). Accordingly, this may represent the first report to examine $\mathrm{C} 3 \mathrm{H}$ in tropical fruits during ripening.

The PAL enzyme has a major role in plants and in the phenylpropanoid biosynthesis compared to $\mathrm{C} 3 \mathrm{H}$, not only because PAL initiates the phenylpropanoid pathway but also because this pathway is responsible for the production of other important secondary metabolites that are necessary for plant-cell life, such as coumarin, lignin, and terpenoids (Cai et al., 2006; Vogt, 2010). Therefore, this may be the reason that the PAL enzyme remained active during all mango ripening stages. Consequently, the relationship of the expression and enzyme activity in mango cultivar 'Ataulfo' with the physiological parameters that were analyzed in a previous study reveals evidence of the roles that are performed by the $P A L$ and $C 3 H$ genes in this process. This study emphasizes the complex nature of the regulation of phenolic compounds in tropical fruits. This work provides valuable information for future research to understand emerging concepts in the regulation of phenolic compound biosynthesis during ripening of tropical fruits. 


\section{ACKNOWLEDGMENTS}

We thank Monica Villegas for technical assistance. H. Palafox-Carlos thanks CONACyT for a doctoral scholarship, M.A. Islas-Osuna thanks CONACyT for \#CB2012-01-178296, and G.A. González-Aguilar thanks CONACyT for Project \#CB2007-C01-80511 grants. We thank Dr. Rogerio R. Sotelo-Mundo for the critical reading of this manuscript.

\section{REFERENCES}

Abdulrazzak N, Pollet B, Ehlting J, Larsen K, et al. (2006). A coumaroyl-ester-3-hydroxylase insertion mutant reveals the existence of nonredundant meta-hydroxylation pathways and essential roles for phenolic precursors in cell expansion and plant growth. Plant Physiol. 140: 30-48.

Almeida JR, D'Amico E, Preuss A, Carbone F, et al. (2007). Characterization of major enzymes and genes involved in flavonoid and proanthocyanidin biosynthesis during fruit development in strawberry (Fragaria x ananassa). Arch. Biochem. Biophys. 465: 61-71.

Assis JS, Maldonado R, Muñoz T, Escribano MI, et al. (2001). Effect of high carbon dioxide concentration on $P A L$ activity and phenolic contents in ripening cherimoya fruit. Postharvest Biol. Tec. 23: 33-39.

Bapat VA, Trivedi PK, Ghosh A, Sane VA, et al. (2010). Ripening of fleshy fruit: molecular insight and the role of ethylene. Biotechnol. Adv. 28: 94-107.

Boudet AM (2007). Evolution and current status of research in phenolic compounds. Phytochemistry 68: 2722-2735.

Cai C, Xua CJ, Li X, Ferguson I, et al. (2006). Accumulation of lignin in relation to change in activities of lignification enzymes in loquat fruit flesh after harvest. Postharvest Biol. Tec. 40: 163-169.

Chen JY, He LH, Jiang YM, Wang Y, et al. (2008). Role of phenylalanine ammonia-lyase in heat pretreatment-induced chilling tolerance in banana fruit. Physiol. Plant 132: 318-328.

Franke R, Humphreys JM, Hemm MR, Denault JW, et al. (2002). The Arabidopsis REF8 gene encodes the 3-hydroxylase of phenylpropanoid metabolism. Plant J. 30: 33-45.

Giovannoni JJ (2004). Genetic regulation of fruit development and ripening. Plant Cell (Suppl 16): S170-S180.

Gonzalez-Aguilar GA, Villa-Rodriguez JA, Ayala-Zavala JF and Yahia EM (2010). Improvement of the antioxidant status of tropical fruits as a secondary response to some postharvest treatments. Trends Food Sci. Tech. 21: 475-482.

Jaakola L, Maatta K, Pirttila AM, Torronen R, et al. (2002). Expression of genes involved in anthocyanin biosynthesis in relation to anthocyanin, proanthocyanidin, and flavonol levels during bilberry fruit development. Plant Physiol. 130: 729-739.

Kumar A and Ellis BE (2001). The phenylalanine ammonia-lyase gene family in raspberry. Structure, expression, and evolution. Plant Physiol. 127: 230-239.

Liu X, Deng Z, Gao S, Sun X, et al. (2008). A new gene coding for P-coumarate 3-hydroxylase from Ginkgo biloba. Russ. J. Plant Physl. 55: 82-92.

Livak KJ and Schmittgen TD (2001). Analysis of relative gene expression data using real-time quantitative PCR and the $2^{-\Delta \Delta C \mathrm{CT}}$ Method. Methods 25: 402-408.

López-Gómez R and Gómez-Lim MA (1992). A method for extracting intact RNA from fruits rich in polysaccharides using ripe mango mesocarp. HortScience 27: 440-442.

Ma X, Wu H, Liu L, Yao Q, et al. (2011). Polyphenolic compounds and antioxidant properties in mango fruits. Sci. Hortic. -Amsterdam 129: 102-107.

Mahesh V, Million-Rousseau R, Ullmann P, Chabrillange N, et al. (2007). Functional characterization of two P-coumaroyl ester 3'-hydroxylase genes from coffee tree: evidence of a candidate for chlorogenic acid biosynthesis. Plant Mol. Biol. 64: 145-159.

Manthey JA and Perkins-Veazie P (2009). Influences of harvest date and location on the levels of $\beta$-carotene, ascorbic acid, total phenols, the in vitro antioxidant capacity, and phenolic profiles of five commercial varieties of mango (Mangifera indica L.). J. Agric. Food Chem. 57: 10825-10830.

Mutch DM, Wahli W and Williamson G (2005). Nutrigenomics and nutrigenetics: the emerging faces of nutrition. FASEB J. 19: 1602-1616.

Nair RB, Xia Q, Kartha CJ, Kurylo E, et al. (2002). Arabidopsis CYP98A3 mediating aromatic 3-hydroxylation. Developmental regulation of the gene, and expression in yeast. Plant Physiol. 130: 210-220.

Palafox-Carlos H, Yahia E, Islas-Osuna MA and Gutierrez-Martinez P (2012a). Effect of ripeness stage of mango fruit (Mangifera indica L., cv. Ataulfo) on physiological parameters and antioxidant activity. Sci. Hortic. 135: 7-13.

Genetics and Molecular Research 13 (2): 3850-3858 (2014) 
Palafox-Carlos H, Yahia EM and González-Aguilar GA (2012b). Identification and quantification of major phenolic compounds from mango (Mangifera indica, cv. Ataulfo) fruit by HPLC-DAD-MS/MS-ESI and their individual contribution to the antioxidant activity during ripening. Food Chem. 135: 105-111.

Pandit SS, Kulkarni RS, Giri AP, Kollner TG, et al. (2010). Expression profiling of various genes during the fruit development and ripening of mango. Plant Physiol. Biochem. 48: 426-433.

Promyou S, Ketsa S and Van Doorn WG (2007). Effect of surface coating on ripening and early peel spotting in 'Sucrier' banana (Musa acuminata). New Zeal. J. Crop Hort. 35: 259-265.

Rinaldo D, Mbéguié-A-Mbéguié D and Fils-Lycaon B (2010). Advances on polyphenols and their metabolism in subtropical and tropical fruits. Trends Food Sci. Tech. 21: 599-606.

Rösler J, Krekel F, Amrhein N and Schmid J (1997). Maize phenylalanine ammonia-lyase has tyrosine ammonia-lyase activity. Plant Physiol. 113: 175-179.

Sanchez-Ballesta MT, Zacarias L, Granell A and Lafuente MT (2000). Accumulation of $P A L$ transcript and $P A L$ activity as affected by heat-conditioning and low-temperature storage and its relation to chilling sensitivity in mandarin fruits. J. Agric. Food Chem. 48: 2726-2731.

Schoch G, Goepfert S, Morant M, Hehn A, et al. (2001). CYP98A3 from Arabidopsis thaliana is a 3'-hydroxylase of phenolic esters, a missing link in the phenylpropanoid pathway. J. Biol. Chem. 276: 36566-36574.

Shan LL, Yuan XY, Mao CP and Ji JF (2008). Characteristics of heavy metals in sediments from different sources and their ecological risks in the lower reaches of the Yangtze River. Huan. Jing. Ke Xue 29: 2399-2404.

Singh R, Rastogi S and Dwivedi UN (2010). Phenylpropanoid metabolism in ripening fruits. Compr. Rev. Food Sci. F. 9: 398-416.

Sreelakshmi Y and Sharma R (2008). Differential regulation of phenylalanine ammonia lyase activity and protein level by light in tomato seedlings. Plant Physiol. Biochem. 46: 444-451.

Vogt T (2010). Phenylpropanoid biosynthesis. Mol. Plant 3: 2-20.

Yingsanga P, Srilaong V, Kanlayanarat S and Noichinda S (2008). Relationship between browning and related enzymes (PAL, PPO and POD) in rambutan fruit (Nephelium lappaceum Linn.) cvs. Rongrien and See-Chompoo. Postharvest Biol. Tec. 50: 164-168. 